\title{
PERUBAHAN POLA LIPUTAN REPORTER TV SELAMA PANDEMI COVID-19
}

\author{
Dede Suprayitno \\ Universitas Paramadina, habibi.ds@ gmail.com
}

\begin{abstract}
Abstrak
Pandemi Corona Virus Disease 2019 (Covid-19) telah mengubah cara hidup masyarakat dunia. Pentingnya menjaga jarak dan ketatnya protokol kesehatan, membuat masyarakat masuk dalam era normal baru. Hal ini juga turut terimbas pada berbagai pekerjaan, termasuk diantaranya reporter televisi. Padahal dalam melaksanakan tugas, reporter memiliki mobilitas tinggi, sering berinteraksi dengan banyak orang dan mengumpulkan data dari banyak sumber baik fisik maupun non-fisik. Kondisi ini menuntut adanya perubahan pola liputan yang terjadi pada reporter TV. Bukan hanya itu, pola produksi berita pun turut berubah. Penggunaan teknologi digital semakin massif baik baik industri maupun masyarakat. Seperti dalam teori ekologi media, masyarakat juga berkembang sebagaimana teknologi juga ikut berkembang. Tujuan dari penelitian ini, guna menggambarkan perubahan produksi berita oleh reporter tv dan mengetahui alternatif apa saja yang dilakukan reporter tv untuk tetap memproduksi berita, di tengah ketatnya pembatasan jarak yang terjadi. Penelitian ini menggunakan pendekatan kualitatif dan metode penelitian studi kasus bersifat deskriptif dengan mengambil contoh kasus praktik reporter di CNBC Indonesia TV. Hasil penelitian ini mendeskripsikan alternatif dan pengembangan teknik liputan oleh reporter TV, dimana penggunaan teknologi menjadi penunjang penting proses produksi.
\end{abstract}

Kata Kunci : reporter tv, teori ekologi media, pola liputan, pandemi corona

\begin{abstract}
The Pandemic Corona Virus Disease 2019 (Covid-19) has changed the way of life of the world community. The importance of maintaining distance and strict health protocols, makes people enter in a new normal era. This has also been affected by a variety of jobs, including television reporters. In fact, in carrying out their duties, reporters have high mobility, often interact with many people and collect data from many physical and non-physical sources. This condition requires a change in coverage patterns that occur in TV reporters. In addition, the pattern of news production also changed. The use of digital technology is increasingly massive both industry and society. As in media ecology theory, society also develops as technology also develops. The purpose of this research is to describe the changes in news production by TV reporters and to find out what alternatives are done by TV reporters to continue producing news, when the restrictions on the distance that occur. This study uses a qualitative approach and the case study method is descriptive by taking the case of reporter practices on CNBC Indonesia TV. The results of this study describe the alternatives and the development of coverage techniques by TV reporters, where the use of technology is an important support of the production process.
\end{abstract}

Keywords: TV reporter, media ecology theory, coverage pattern, Corona pandemic

\section{PENDAHULUAN}

Pada penghujung 2019, dunia digegerkan dengan penyebaran kasus pneumonia yang terdeteksi di Wuhan, China. Saat itu, belum dikenal nama penyakit tersebut. Baru pada 31 Desember 2019, China melaporkan temuan kasus tersebut kepada
World Health Organization (WHO). Selang sepekan atau pada 7 Januari 2020, pihak berwenang China mengonfirmasi penyakit tersebut sebagai virus corona baru. Awalnya WHO menyebut 2019-nCoV. Namun nama virus ini kemudian berubah menjadi Corona Virus Disease 2019 (Covid-19). 
Penyebaran virus yang demikian cepat, membuat WHO meningkatkan status Covid-19 sebagai pandemi. Tepatnya pada 11 Maret 2020 saat wabah corona ini menyebar hingga ke Turki, Pantai Gading, Honduras, dan Bolivia. Lonjakan kasus harian secara drastis juga dialami di Qatar, dari 24 kasus menjadi 626 kasus. Di Indonesia, penyebaran virus corona pertama kali dilaporkan pada 2 Maret 2020. Virus itu menulari 2 warga negara Indonesia (WNI). Pemerintah yang sebelumnya menyangkal adanya penularan virus, kini terpatahkan. Penyebaran virus corona kian masif di Indonesia.

Pemerintah Indonesia menerapkan kebijakan Pembatasan Sosial Berskala Besar (PSBB) untuk mencegah penyebaran virus secara masif. Masyarakat mulai dilarang untuk bepergian keluar rumah, kecuali untuk kegiatan yang diperbolehkan. Volume angkut transportasi umum dikurangi, guna tetap menjaga jarak sosial. Banyak daerah di Indonesia mulai mengajukan PSBB, bahkan ada yang terus diperpanjang saat mengetahui penyebaran virus corona belum mereda.

Virus corona menciptakan ketakutan di Indonesia. Beberapa pejabat pun dikonfirmasi positif menderita virus corona. Diantaranya seperti Menteri Perhubungan Budi Karya Sumadi dan Wali Kota Bogor Bima Arya Sugiarto. Hal ini menuntut pemerintah untuk serius menangani penyebaran virus corona. Pun demikian halnya dengan masyarakat, selalu diminta untuk menaati protokol kesehatan selama pandemi terjadi. Terutama protokol untuk selalu menjaga jarak aman.

Penerapan PSBB di beberapa daerah turut berimbas pada industri. Baik itu kecil, menengah, hingga besar. Di DKI Jakarta, Gubernur Anies Baswedan pertama kali menerapkan PSBB pada Jumat, 10 April 2020. Dalam peraturan Gubernur Nomor 33 Tahun 2020 tentang pelaksanaan Pembatasan Sosial Berskala Besar (PSBB) di DKI Jakarta, disebutkan sektor-sektor yang dikecualikan sehingga dapat tetap beroperasi. Antara lain seperti kesehatan, bahan pangan, makanan dan minuman, energi, komunikasi dan teknologi, keuangan, logistik, konstruksi, industri strategis, pelayanan dan utilitas publik serta industri yang ditetapkan sebagai objek vital atau objek tertentu dan sektor swasta yang melayani kebutuhan sehari-hari.

Sektor komunikasi termasuk diantaranya media, menjadi industri yang dibolehkan tetap beroperasi. Meskipun jam kerja sehari-harinya terpangkas. CNBC Indonesia TV adalah salah satu media yang turut menerapkan adanya pembatasan sosial selama PSBB di DKI Jakarta berlangsung. Terjadi perubahan pola kerja selama masa PSBB dibandingkan dengan masa sebelumnya. Perubahan pola juga turut terjadi pada kerja reporter TV dalam memproduksi berita.

Padahal dalam keseharian, tugas reporter memiliki mobilitas yang tinggi. Belum lagi mereka harus bertemu dengan banyak orang untuk mengumpulkan informasi. Termasuk bertemu dengan narasumber. Sontak, saat PSBB ramai diterapkan semua itu menghilang. Sementara reporter tetap memiliki tanggung jawab untuk memproduksi berita, sebagai bagian dari pekerjaan.

Pada masa pandemi corona seperti saat ini, bukan hanya bidang media saja yang terimbas. Namun bidang industri lain seperti maskapai penerbangan dan pariwisata merasakan pukulan yang paling keras. Setelah merasakan PSBB sejak April, tak semua industri mampu bertahan. Oleh karena itu, pemerintah juga mulai membuka kembali perekonomian. Masyarakat mulai dikenalkan dengan konsep new normal sebagai sebuah tatanan hidup yang baru.

Konsep new normal rupanya juga memaksa masyarakat Indonesia untuk secara cepat masuk ke era 4G hingga 5G. Penggunaan teknologi yang massif menjadi alternatif di tengah pembatasan sosial yang masih jadi acuan protokol kesehatan.

$$
\text { Dalam dunia broadcasting, }
$$
perusahaan media juga dituntut untuk meningkatkan kemampuan teknologinya. Hal ini menjadi penyesuaian untuk menjawab perubahan yang sedemikian cepat. Penggunaan teknologi yang masif itu turut mendapat kemudahan, lantaran masyarakat 
juga melakukan penyesuaian. Misalnya saja, saat wawancara di televisi kini sering menggunakan metode jarak jauh. Dengan bantuan aplikasi Skype atau Zoom, wawancara jarak jauh kini bisa terjadi.

Meskipun, penerapan konvergensi media dengan menggunakan teknologi 4GLTE masih terkendala masalah biaya yang mahal dan kualitas jaringan yang masih terbatas, sehingga hanya media-media dengan fondasi keuangan yang kuat yang dapat melakukannya. (Gemiharto, 2015).

Segera berlakunya kembali produksi media ini tak terlepas dari kepentingan pemilik modal. Morrisan (dalam Hidayat, 2015) menyebut ada dua tantangan yang dihadapi oleh manajemen media penyiaran. Pertama, media penyiaran dalam kegiatan operasionalnya harus dapat memenuhi harapan pemilik dan pemegang saham untuk menjadi perusahaan yang sehat dan mampu menghasilkan keuntungan. Kedua, media penyiaran harus mampu memenuhi kepentingan masyarakat (komunitas) dimana media bersangkutan berada, sebagai ketentuan yang harus dipenuhi ketika media penyiaran bersangkutan menerima izin siaran (lisensi) yang diberikan negara.

Dengan demikian, untuk menjaga keberlangsungan usaha media penyiaran, manajemen $\mathrm{CNBC}$ Indonesia turut mempertimbangkan pemberlakuan kembali jam kerja normal selama pandemi Covid-19. Dengan catatan tetap menerapkan protokol kesehatan yang ketat. Hal ini turut menegaskan pernyataan Peter Priangle (dalam Hidayat, 2015) bahwa mengelola media penyiaran memberikan tantangan yang tidak mudah. "Few management position offers challengers equal to those of managing a commercial radio or television station."

Sebagai media yang belum genap 2 tahun, CNBC Indonesia TV dihadapkan pada situasi yang sulit saat pandemi. Meski demikian, life must go on dan manajemen memutuskan CNBC Indonesia TV tetap beroperasi kembali dengan jam penuh. Dipilihnya CNBC Indonesia TV sebagai penelitian disebabkan media ini menjadi salah satu yang melakukan terobosan penting dalam teknologi penyiaran. Dimana penggunaan teknologi berbasis digital, menjadi strategi utama untuk memperluas cakupan konten.

Selain itu, CNBC Indonesia yang bernaung dalam grup Transmedia, cukup intens dalam melakukan konvergensi media. Hal ini tak lain sebagai langkah optimalisasi sumber daya perusahaan. Di tengah masa pandemi Covid-19, konvergensi media menjadi sebuah keniscayaan yang dapat dilakukan oleh perusahaan media. Saat ketatnya aturan menjaga jarak, orang-orang mulai banyak didorong untuk menggunakan teknologi sebagai bagian dari kehidupan yang tidak terpisahkan.

Berdasar latar belakang masalah tersebut, rumusan masalah penelitian ini antara lain: seperti apa perubahan pola liputan reporter TV selama masa pandemi Covid-19? Perubahan apa saja yang signifikan terjadi dalam proses produksi di CNBC Indonesia TV? Bagaimana adaptasi media elektronik saat ini, terhadap perubahan teknologi yang sedemikian cepat?

Penelitian ini bertujuan mengetahui perubahan pola liputan yang juga terjadi seiring dengan ketatnya pembatasan jarak yang terjadi di masyarakat. Selain itu juga menggambarkan, perubahan yang terjadi dalam proses produksi berita di CNBC Indonesia TV. Secara holistik, penelitian ini juga untuk mengetahui perubahan apa saja yang terjadi dalam industri media, khususnya televisi selama masa pandemi Covid-19.

\section{KAJIAN LITERATUR}

\section{Komunikasi Massa}

Komunikasi massa telah mengalami perkembangan yang sangat pesat, seiring dengan kemajuan teknologi era digital saat ini. Hal ini turut membuat studi komunikasi menjadi berkembang lebih luas. Dalam praktiknya, komunikasi massa berhubungan dengan khalayak ramai dan menggunakan saluran tertentu, untuk menyampaikan pesan. Baik itu menggunakan media cetak, elektronik, maupun digital.

George Gerbner, pencetus teori kultivas, mengemukakan komunikasi massa sebagai proses produksi dan distribusi, yang 
berlandaskan teknologi dan lembaga. Proses ini membuat arus pesan yang berkelanjutan dan luas pada masyarakat industri. Organisasi media dalam hal ini, membuat dan menyebarkan berita kepada khalayak luas. Sehingga dapat memengaruhi cara pandang masyarakat terhadap suatu hal. Komunikasi massa juga cenderung berlangsung dengan satu arah, sehingga komunikator harus memiliki perencanaan yang matang.

Terkait dengan komunikasi massa, Halik (2013) menjelaskan komunikasi massa dengan dua cara pandang. Diantaranya yakni bagaimana orang memproduksi pesan dan menyebarkannya melalui media. Disisi lain, juga bagaimana orang mencari serta menggunakan pesan-pesan tersebut pada pihak lainnya. Pengkajian komunikasi massa banyak dipengaruhi oleh dinamika media massa dan penggunaannya oleh khlayak. Pesan yang dipahami dalam proses komunikasi massa, memerlukan keterampilan khusus. Diantaranya seperti kemampuan melek huruf, penggunaan teknologi, serta memahami secara kontekstual.

Media massa menjadi sarana utama dalam praktik komunikasi massa. Media hadir dengan memberikan pengaruh pada masyarakat. Sementara itu, masyarakat akan merespon pengaruh tersebut, dan membagikannya pada pihak lain. Terdapat aliran informasi yang berlangsung dalam cakupan luas. Sifatnya cenderung cepat dan dinamis, sehingga komunikator dituntut untuk menjadi sumber informasi yang matang. Media massa kini telah berkembang menjadi berbagai macam platform.

\section{Ekologi Media}

Dalam teori ekologi media, masyarakat juga berkembang sebagaimana teknologi juga ikut berkembang. Sehingga bila media mengikuti perkembangan teknologi yang ada, daya jangkau informasi menjadi lebih luas. Dengan kata lain, teknologi mampu mempengaruhi komunikasi lewat media.

Teknologi membawa perubahan dalam cara masyarakat menggunakan media. McLuhan menggarisbawahi bahwa medium adalah pesan itu sendiri. Dengen perkataan lain, bentuk-bentuk baru media mentransformasikan (pesan) pengalaman. Pengaruh ini jauh lebih penting daripada konten yang ditransmisikan dalam pesan spesifiknya- teknologi menentukan pengalaman (Baran dan Davis, 2010).

McLuhan dalam buku Understanding Media (1964) juga menyebut bahwa media adalah perpanjangan tangan dari manusia dan berargumen bahwa media secara harfiah memperpanjang pandangan, pendengaran, serta sentuhan melalui ruang dan waktu. Everett Rogers (dalam Baran dan Davis, 2010) menegaskan perspektif McLuhan berhak mendapat perhatian, terutama dalam mempelajar media baru.

Teori ekologi media memiliki prinsip bahwa masyarakat tidak bisa terhindar dari pengaruh teknologi. Teknologi mempersatukan masyarakat, dan akan tetap menjadi pusat kehidupan virtual manusia. Teknologi juga merupakan salah satu unsur dari kebudayaan yang melekat pada manusia. Teori ini juga menegaskan bahwa masyarakat dan teknologi telah berevolusi.

\section{New Media}

Pembahasan mengenai new media atau media baru, erat berkaitan dengan kemajuan pesat teknologi. Dalam beberapa tahun terakhir, teknologi membawa perubahan yang sangat signifikan, dalam tiap sendi kehidupan manusia. Media baru menghadirkan ruang-ruang eksplorasi baru, yang lebih luas, tidak terbatas, dan memiliki dimensi cepat.

Media baru juga menjadi alat untuk memuluskan informasi dari satu pihak ke masyarakat. Perkembangan media baru, memberi warna bagi kajian komunikasi massa. Pada masyarakat kontemporer, kehadiran media baru menjadi alternatif yang ajaib untuk membuka ruang-ruang baru. Kehadiran media baru dapat meningkatkan interaksi sosial antarmanusia. Dari yang sebelumnya, terbatas pada sekat-sekat geografis, kini terbuka dan menjadi ruang baru dalam berinteraksi.

Lister, dkk (2009) menyatakan media baru merupakan sebuah istilah yang merujuk 
pada berbagai perubahan yang ada dalam proses produksi, distribusi, dan penggunaan media. Oleh karena itu, media baru memiliki beberapa karakteristik. Diantaranya sebagai berikut:

1) Digital

Informasi berupa data diolah menjadi angka yang bisa dibaca oleh mesin. Bila proses analog atau konvensional masih menggunakan proses fisik, maka proses digital memungkinkan informasi untuk berpindah dengan cepat. Bukan hanya itu, digital juga mampu menampung informasi dalam jumlah yang sangat besar. Transformasi data inilah yang membuat konsep digital memiliki kelebihan berupa akses informasi yang cepat dan beragam.

2) Interaktivitas

Media konvensional memiliki keterbatasan dalam membuka ruang interaktif. Sekalipun bisa, maka memerlukan waktu yang lebih lama. Berbeda halnya dengan media baru, yang membuat interaksi menjadi terbuka lebar. Dengan basis digital, akses dan pertukaran data menjadi cepat. Termasuk diantaranya dalam mengakomodasi adanya interaksi. Media baru menghadirkan perubahan pola komunikasi. Dari yang awalnya bersifat satu arat, kini bisa dua arah. Sehingga tercipta adanya pertukaran informasi. Kehadiran interaktivitas, membuat rasa keterlibatan pengguna menjadi lebih kuat, relasi yang lebih independen dengan sumber pengetahuan, dan membuka berbagai pilihan yang lebih besar pada pengguna.

3) Hipertekstual

Karakteristik ini merujuk pada ketersediaan informasi yang mudah pada media baru. Antara lain berupa kemudahan akses informasi dimana dan kapan saja. Banyak informasi yang ada dalam media baru, namun pengguna bisa memilih informasi mana saja yang dibutuhkan. Pengguna juga dapat menemukan informasi mana saja yang dibutuhkan melalui fitur media baru. Diantaranya melalui jaringan informasi dan navigasi tekstual yang dapat membantu pengguna mendapatkan informasi yang diinginkan.

4) Jaringan
Informasi dalam media baru terkoneksi satu sama lain. Informasi yang ada dalam perangkat digital, bisa diakses oleh siapapun dalam waktu bersamaan. Hal ini memungkinkan pertukaran informasi semakin beragam, namun rawan dalam hal pencurian data.

\section{5) Virtual}

Media baru membuka ruang dalam ranah virtual. Diantaranya ruang, objek, lingkungan, kenyataan, diri dan identitas. Virtual juga sering disebut sebagai salah ciri budaya postmodern dan masyarakat yang maju secara teknologi, dimana begitu bayak aspek pengalaman sehari-hari, dapat disimulasikan melalui teknologi.

6) Simulasi

Media baru dapat menghadirkan sensasi bagi penggunanya. Untuk merasakan langsung apa yang sebenarnya terjadi pada sebuah peristiwa atau informasi. Adanya penggabungan antara audio, visual, dan rangsangan indera lain akan merekayasa tubuh dan pikiran pengguna. Guna mencapai titik pemahaman informasi yang lebih maksimal. Sehingga pengguna seolah-olah menjadi salah satu subjek dalam suatu peristiwa.

Beberapa ciri karakteristik media baru diatas, bisa saja tidak hadir seluruhnya dalam satu media. Namun dalam kenyataannya, kehadiran karakteristik tersebut akan memiliki ukuran yang berbeda-beda.

\section{Konvergensi Media}

Perkembangan teknologi informasi yang pesat, membawa perubahan signifikan bagi kehidupan masyarakat. Terutama teknologi informasi berupa jaringan internet, yang mampu membangun hubungan secara global, membuka sekat-sekat yang selama ini terbatasi oleh ruang dan waktu. Perkembangan ini pun berdampak pada kehidupan sosial sehari-hari di masyarakat. Integrasi internet ke dalam dunia kehidupan telah menciptakan bentuk baru identitas sosial dan juga ketidaksetaraan di masyarakat (Castells dalam Sugihartati, 2014).

Mc Luhan juga menyebut internet akan membawa masyarakat pada konsep

SSN: 2355-0287, E-ISSN: 2549-3299

http://ejournal.bsi.ac.id/ejurnal/index.php/jika 
"global village", dimana masyarakat dapat terkoneksi satu sama lain tanpa ada batasan apapun. Masyarakat global dapat berinteraksi tanpa sekat geografis yang menghalangi. Arus informasi akan terjadi sedemikian deras. Internet memberikan akselerasi dalam dunia komunikasi, sehingga akan memberikan dampak yang signifikan bagi kehidupan sosial masyarakat. Diantaranya membuka ruangruang baru bagi masuknya budaya-budaya lain dalam sistem masyarakat.

Penggunaan internet menjadi bagian yang tidak terpisahkan dalam kehidupan masyarakat. Pemerintah Indonesia juga mengupayakan, peningkatan akses internet di tanah air. Salah satu program yang cukup popular yakni dengan dibangunnya jaringan kabel optik (backbone) Palapa Ring. Kabel ini terbentang dari barat, tengah dan timur Indonesia.

$\begin{array}{ccc}\begin{array}{c}\text { Palapa } \\ \text { infrastruktur }\end{array} & \begin{array}{c}\text { Ring merupakan } \\ \text { telekomunikasi }\end{array} & \begin{array}{c}\text { proyek } \\ \text { berupa }\end{array}\end{array}$
pembangunan serat optik di seluruh Indonesia sepanjang 36.000 kilometer. Pembangunan jaringan serat optik nasional ini akan menjangkau 440 kota/kabupaten di seluruh Indonesia. Proyek Palapa Ring ini akan mengintegrasikan jaringan yang sudah ada (existing network) dengan jaringan baru (new network) pada wilayah timur Indonesia (Palapa Ring-Timur).

Jaringan ini akan menjadi tumpuan semua penyelenggara telekomunikasi dan pengguna jasa telekomunikasi di Indonesia. Jaringan ini juga akan mengintegrasikan dengan jaringan yang telah ada dari penyelenggara telekomunikasi. Sehingga dapat memberikan akselerasi pertumbuhan dan pemerataan pembangunan sosial ekonomi melalui ketersediaan infrastruktur jaringan internet berkapasitas besar.

Akselerasi teknologi internet di tanah air, turut berperan dalam mempercepat arus konvergensi media. Tanpa internet yang cepat, berkualitas tinggi, aman dan murah, maka arus konvergensi media akan butuh waktu yang lebih lama. Imbasnya, ini akan mempengaruhi arus informasi di masyarakat, dan bagi industri akan memberikan pengaruh dari besarnya ongkos yang harus dikeluarkan.
Dalam perspektif ekonomi media, teknologi memiliki peran penting dalam industri media. Industri media massa harus senantiasa mengikuti perkembangan teknologi (Usman dalam Resmadi, 2014). Teknologi turut memperluas cakupan penetrasi yang dapat dilakukan oleh media. Sehingga konten yang diproduksi dapat menyebar lebih luas. Hanya saja, untuk memiliki teknologi yang mutakhir, perusahaan membutuhkan investasi besar.

Konvergensi industri media dan teknologi digital mengarah pada bentukbentuk yang dikenal sebagai komunikasi multimedia. Multimedia atau dikenal juga sebagai media campuran, pada umumnya didefinisikan sebagai medium yang mengintegrasikan dua bentuk komunikasi atau lebih (Fiddler dalam Resmadi, 2014). Salah satu langkah yang ditempuh dalam meningkatkan nilai praktik bisnis, perusahaan melakukan konvergensi media. Persaingan antar media juga semakin ketat, seiring dengan naiknya jumlah media (Hidayat, 2015).

\section{METODE PENELITIAN}

Penelitian ini menggunakan pendekatan kualitatif. Yakni metode untuk mengeksplorasi dan memahami makna -oleh sejumlah individu atau sekelompok orangdianggap berasal dari masalah sosial atau kemanusiaan. Proses penelitian kualitatif melibatkan upaya-upaya penting, seperti mengajukan pertanyaan- pertanyaan atau prosedur-prosedur, mengumpulkan data yang spesifik dari para partisipan, menganalisis data secara induktif mulai dari tema-tema yang khusus, ke tema-tema umum dan menafsirkan makna data (Creswell, 2010). Penelitian kualitatif didasarkan pada konteks lokal tempat fenomena berlangsung, generalisasi hasil penelitian terhadap populasi yang lebih besar atau situasi lain menjadi problematik (Lee dalam Mulyana, 2013).

Sedangkan jenis penelitian ini merupakan deskriptif. Yakni bertujuan membuat deskripsi secara sistematis, faktual, dan akurat tentang fakta- fakta dan sifat-sifat populasi atau objek tertentu (Kriyantono, 
2014). Penelitian deskriptif merupakan pengukuran yang cermat terhadap fenomena sosial tertentu (Singarimbun dan Effendi dalam Bajari, 2015). Tujuan dari penelitian deskriptif yakni mengembangkan konsep dan menghimpun fakta-fakta, bukan menguji hipotesis. Penelitian deskriptif berusaha menemukan pola sederhana yang didasarkan pada konsep tertentu (Bajari, 2015).

Sementara itu, penelitian ini menggunakan metode studi kasus. Sehingga menuntut peneliti cermat dalam menyelidiki suatu program, peristiwa, aktivitas, proses atau sekelompok individu. Kasus-kasus yang terjadi akan dibatasi oleh waktu dan aktivitas. Peneliti mengumpulkan informasi secara lengkap dengan menggunakan berbagai prosedur pengumpulan data berdasarkan waktu yang telah ditentukan (Stake dalam Creswell, 2010). Metode studi kasus memusatkan diri secara intensif terhadap suatu objek tertentu dengan cara mempelajari sebagai suatu kasus.

\section{Teknik Pengumpulan Data}

Dalam penelitian ini, penulis menghimpun dan menganalisis fakta-fakta yang ada di lapangan. Diantaranya merekam perubahan pola liputan reporter CNBC Indonesia TV selama terjadi pandemi Covid19. Untuk mendapatkan data, penulis melakukan pengumpulan data melalui wawancara dan studi pustaka.

Sumber primer dalam penelitian ini yakni hasil wawancara dengan Koordinator Peliputan CNBC Indonesia TV, diantaranya Ayos, Wahyu, dan Lucky Devianto Kurniawan. Penulis juga merangkum pandangan secara holistik, dengan melakukan wawancara dengan Kepala Peliputan Berita dan Sosial CNBC Indonesia, Novan Dwi Putranto. Wawancara dilakukan di kantor CNBC Indonesia di gedung Transmedia Lt. 3A Jl. Kapten P. Tendean Kav 12-14a Mampang Prapatan, Jakarta Selatan. Sementara itu, sumber sekunder penelitian berasal dari buku, jurnal dan website terkait dengan aktivitas jurnalistik.

Pemilihan narasumber yang dilakukan penulis, menggunakan prosedur purposif.
Bungin (2011) menyebut prosedur purposif dilakukan dengan menentukan kelompok peserta yang menjadi informan sesuai dengan kriteria terpilih yang relevan dengan masalah penelitian tertentu. Pemilihan narasumber dilakukan dengan pertimbangan: koordinator peliputan memiliki wewenang dalam hal memberikan penugasan kepada reporter; (2) kepala peliputan berita dan sosial memiliki wewenang dalam menentukan pengembangan kemampuan reporter; (3) pegawai CNBC Indonesia; (4) turut menentukan agenda setting pemberitaan media yang dirancang di newsroom; (5) memiliki wewenang dalam pengembangan sumber daya reporter. Selain itu, narasumber merupakan praktisi yang berpengalaman di bidangnya.

\section{PEMBAHASAN}

CNBC Indonesia TV memulai tonggak bersejarah siaran perdananya pada 10 Oktober 2018. Kedatangan CNBC Indonesia TV kian menambah daftar saluran televisi di Indonesia. CNBC Indonesia TV merupakan channel televisi ekonomi pertama di Indonesia. Lahirnya CNBC Indonesia TV, tak lepas dari kolaborasi Trans Media dengan NBC Universal International.

NBCUniversal International adalah konglomerasi media asal Amerika Serikat. NBCUniversal masuk dalam jaringan media milik Comcast. Perusahaan ini memiliki cabang di berbagai negara. Antara lain seperti India, Jepang, Singapura, Australia, Hong Kong, dan juga Indonesia.

CNBC Indonesia mengusung tagline beyond business. Ini menjadi impian bagi CNBC Indonesia untuk memberikan nilai tambah bagi audiens. Bukan hanya untuk menyediakan informasi lewat televisi saja, namun juga melalui aplikasi, website, dan sejenisya.

Ketika melakukan Grand Launching pada 2018, CNBC Indonesia menempatkan diri sebagai media yang berfokus pada kajian ekonomi. Kegiatan ini berlangsung dengan baik, bersamaan dengan agenda IMF World Bank Annual Meeting 2018 di Nusa Dua, Bali. 
Belum genap 2 tahun, CNBC Indonesia TV harus menghadapi kenyataan pahit dengan tersebarnya virus corona. Hal ini turut berimbas negatif bagi produktivitas CNBC Indonesia TV. Pasalnya selama kurang lebih 2 bulan, durasi siaran berkurang drastis. Dari sebelumnya bisa 6 program, kala pembatasan sosial berskala besar (PSBB) berlaku menjadi 2 program per harinya.

Program televisi yang berkurang membuat banyak tenaga menjadi menganggur. Yakni saat diberlakukan bekerja dari rumah atau work from home (WFH). Belum lagi adanya PSBB DKI Jakarta, hal ini membuat pergerakan reporter terbatas. Bahkan reporter sempat tidak bisa memproduksi berita di lapangan karena ketatnya peraturan. Hanya saja seiring dengan bekal protokol kesehatan yang dipahami, mereka mulai bisa berburu informasi.

\section{Kreativitas Produksi}

Ada perubahan besar yang terjadi atas pola liputan reporter TV selama pandemi. Ketatnya perusahaan dalam menjalankan protokol kesehatan, membatasi ruang gerak reporter dalam mencari berita. Hal ini turut berdampak bagi liputan reporter TV. Adanya pandemi ini membuat reporter TV harus semakin kreatif mengemas konten informasi. Diantaranya dengan memanfaatkan teknologiteknologi baru.

"Upgrade of technological and communication means has created new communication channels, which offer and abundance of information sources to the modern man, as well as platforms for their tranfer and placement." (Stamenkovic dkk., 2018)

Koordinator Peliputan CNBC Indonesia TV, Ayos mengungkapkan bila sebelum pandemi liputan reporter berdasarkan agenda, atau membahas topik dan isu yang sedang ramai. Namun saat pandemi corona, agenda liputan langsung sangat terbatas. Padahal reporter TV memiliki basis informasi audio visual.

"Ada perubahan paradigma yang besar soal liputan. Perubahannya sekarang adalah liputannya janjian dengan narasumber. Jadi bikin paket berita 1 on 1 , dan sebagainya. Sekarang polanya begitu, karena modelnya sudah berbeda, jadi kita bikin agenda tersendiri dari korlip (koordinator peliputan). Seekstrim apa pun pemerintah ada pembatasan, reporter TV itu tetap harus bergerak keluar. Gak bisa mengurung diri, karena gambar itu dinamis, berubah terus," (Ayos, CNBC Indonesia TV).

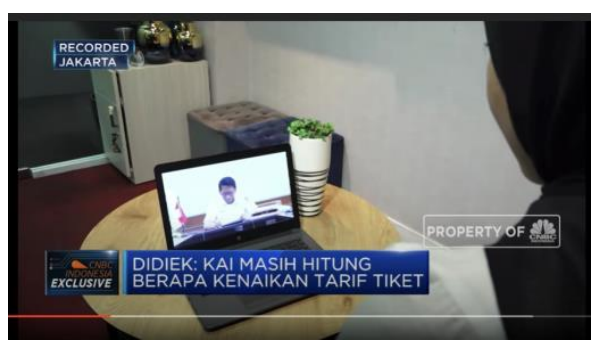

Gambar 1. Model wawancara 1 on 1 dengan narasumber menggunakan teknologi digital

Sumber: YouTube CNBC Indonesia

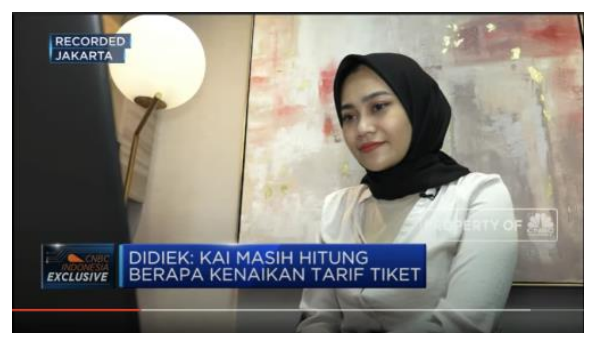

Gambar 2. Model wawancara 1 on 1 dengan narasumber menggunakan teknologi digital

Sumber: YouTube CNBC Indonesia

Agenda sebelum liputan reporter, umumnya korlip dapatkan dengan meriset isu apa yang sedang ramai dibicarakan. Selain itu, korlip juga akan berdiskusi dengan tim produksi, untuk membahas isu bersama atau memehuhi permintaan liputan dari tim produksi.

Sementara untuk taping virtual, reporter TV diberikan target dalam 1 bulan setidaknya ada 2 sampai 3 orang direktur utama dari sebuah perusahaan. Sedangkan opsi jabatan setingkat direksi bisa menjadi pilihan kedua. Reporter juga ditugaskan untuk mencari narasumber penting, untuk memenuhi tugas paket liputan virtual.

"Sekarang polanya bikin sendiri. Ini namanya paket wawancara 1 on 1 , ada juga 
paket berita taping virtual. Jadi selama vaksin belum ditemukan, reporter TV pergerakannya jadi terbatas. Sekarang lebih banyak pergerakan yang sifatnya riil mandiri dan lebih kreatif lagi," (Ayos, CNBC Indonesia TV).

Menurut Ayos, saat ini hampir 90\% undangan liputan banyak melalui zoom atau skype. Sisanya $10 \%$ masih ada yang mengundang secara langsung dan umumnya merupakan acara seremonial. Misalnya saja saat melakukan kunjungan kerja, survei harga, survei stok bahan pangan, dan lain-lain. Hal ini berbeda sekali dengan masa sebelum pandemi, dimana masih banyak terdapat agenda langsung di lapangan, dan belum melalui aplikasi digital.

Koordinator Peliputan CNBC Indonesia TV, Wahyu mengutarakan kini reporter banyak ditugaskan secara online. Dengan memanfaatkan wawancara melalui zoom. Liputan dilakukan dengan narasumber prominent terkait isu terbaru. Selain itu, koordinator liputan juga menugaskan campers yang tidak turun ke lapangan, untuk bertugas di kantor guna mengambil gambar-gambar dengan sudut terbaik.

"Untuk mempercantik layar, tugas juru kamera mengambil angle bagus, hingga melakukan taping ulang untuk reporter. Agar menjadi paket berita dengan visual yang layak," (Wahyu, CNBC Indonesia TV)

\section{Beralih Platform Media}

Komunikasi yang sudah dikonvergensikan menyediakan berbagai macam alat untuk penyampaian berita dan memungkinkan konsumen untuk memilih tingkat interaktivitasnya, seraya mereka bisa mengarahkan sendiri penyampaian kontennya. (Haqqu, 2020). Keberadaan media konvergen memunculkan karakter baru yang makin interaktif, dimana penggunanya mampu berkomunikasi secara langsung dan memperoleh konsekuensi langsung atas pesan (Severin \& James, dalam Haqqu, 2020).

Praktik konvergensi media, terjadi pada CNBC Indonesia TV. Tatkala pergerakan reporter TV yang terbatas, membuat tenaga mereka menjadi menganggur (idle). Sewaktu- waktu koordinator peliputan menugaskan reporter untuk menulis berita pada platform digital CNBCIndonesia.com. Hal ini menjadi salah satu langkah kolaborasi media CNBC Indonesia dibawah naungan Transmedia.

Dalam praktiknya saat terjadi work from home di masa PSBB, reporter TV yang idle, juga menulis berita-berita untuk digital. Sumber berita tersebut, diantaranya berasal dari seminar online, press conference, maupun dialog yang terjadi di CNBC Indonesia TV yang umumnya menggunakan streaming media. Selain itu, reporter TV juga bisa menulis berita dengan sumber yang dihasilkan sendiri. Dengan kata lain, reporter mengontak langsung narasumber dan bertanya tentang isu tertentu.

Jumlah reporter CNBC Indonesia TV ada 5 orang. Kurang lebih sebanyak $95 \%$ tulisan mereka, dipublikasikan lewat platform digital. Ini menjadi langkah untuk meningkatkan produktivitas reporter di saat kondisi yang penuh dengan pembatasan sosial. Sementara itu, untuk taping wawancara virtual, reporter TV masih harus pergi ke kantor. Hal ini ditujukan agar menjaga stabilitas jaringan internet ketika wawancara berlangsung. Selain itu, reporter juga lebih mudah melakukan koordinasi dengan korlip.

$$
\text { Koordinator Peliputan CNBC }
$$

Indonesia, Wahyu mengutarakan metode reporter menulis untuk platform digital berlaku saat work from home saja. Ini merupakan alternatif yang dilakukan oleh koordinator peliputan, melihat adanya pembatasan tim di lapangan. Pada waktu WFH, hanya ada 1 reporter saja dari total 5 reporter yang bertugas, untuk turun langsung ke lapangan. Biasanya 1 reporter tersebut membuat paket berita atau melakukan live report. Sementara 4 reporter lainnya membantu penugasan tim platform digital.

Ketika salah satu saluran produksi informasi terkendala, media akan menemukan alternatif cara lain untuk bisa menyalurkan informasi. Di era konvergensi media saat ini, hal itu sangat mungkin terjadi. Pesatnya perkembangan dunia digital, membuka ruangruang baru, yang semakin mudah dijangkau.

"Convergence represents a cultural 
shift as consumers are encouraged to seek out new information and make connections among dispersed media content.....If the digital revolution paradigm presumed that new media would displace old media, the emerging convergence paradigm assumes that old and new media will interact in ever more complex ways." (Jenkins: 2006).

\section{Pekerjaan Terdisrupsi}

Adanya pandemi

corona, menghasilkan disrupsi bagi bidang camera person (campers). Koordinator Peliputan CNBC Indonesia TV, Lucky Devianto Kurniawan menyebut posisi campers saat ini tergantikan dengan adanya teknologi zoom dan skype. Kebutuhan gambar dapat dipenuhi dari agenda-agenda streaming yang dilakukan oleh institusi tertentu. Dimana tidak memerlukan kehadiran campers di lokasi press conference.

"Campers terdampak kalau (pandemi corona) ini lebih lama. Campers jadi kurang efektif juga. Bisa jadi dipikir pakai streaming sudah layak tayang. Fungsi campers ini agak berbahaya, dan bisa jadi pengurangan dan sebagainya. Istilahnya bukan campers pun bisa mendukung tayangan. Orang IT pun yang memahami sistem streaming pun sudah bisa siaran. Ini jadi isu juga di campers," (Lucky, CNBC Indonesia TV)

Rupanya hal ini juga menjadi kekhawatiran bagi pekerjaan campers. Bisa jadi tugas mereka di masa mendatang akan tergantikan oleh mesin. Pasalnya kebutuhan gambar berita dapat dipenuhi lewat streaming media, sehingga mengambil alih pekerjaan campers. Lebih lanjut Lucky menyatakan, seluruh campers tidak semua bisa dialokasikan ke penugasan lain. Sehingga adanya tenaga yang menganggur dapat menjadi ancaman bagi keberlangsungan pekerjaan campers.

"Sekarang tayangan minimalis dengan streaming pun sudah menjanjikan. Standar streaming sudah memenuhi dari sisi teknik, sampai bisa muncul di YouTube. Resolusi audio tayangan sebagian sudah bagus. Tapi komposisi masih kurang," (Lucky, CNBC Indonesia TV).
Kualitas gambar yang dilakukan lewat streaming media belum seluruhnya memenuhi standar jurnalisme televisi. Beberapa diantaranya masih memiliki kualitas resolusi yang rendah, sehingga gambar kabur. Selain itu, kualitas suara juga masih belum terpenuhi dengan baik. Padahal suara menjadi hal yang penting, dan berperan sebagai pengganti bila gambar pun tidak memenuhi standar jurnalistik.

Solusi yang terjadi pada posisi campers saat ini, umumnya dialokasikan pada penugasan lain. Diantaranya seperti liputan tematik, paket berita, paket iklan client, wawancara 1 on 1 atau bahkan dipindahkan dengan tugas baru seperti editor maupun lighting. Di CNBC Indonesia TV, saat ini ada 11 orang campers yang bertugas baik di studio maupun lapangan.

Adanya pembatasan jarak membuat masyarakat kini harus membiasakan diri untuk memanfaatkan teknologi sebagai bagian dari budaya berkomunikasi. Hal ini juga nampak dari cara berkomunikasi sumber berita, yang banyak melakukan distribusi informasi melalui teknologi digital.

Sayangnya, sebagian masih belum memenuhi standar baku produk jurnalistik TV. Beberapa diantaranya masih belum mempertimbangkan dengan detail komposisi gambar, pencahayaan, kualitas suara, dan sejenisnya. Sehingga apabila standar tersebut terganggu, maka produksi bisa terkendala. Seperti yang disampaikan Kepala Peliputan Berita dan Sosial CNBC Indonesia, Novan Dwi Putranto dalam wawancara berikut ini:

"Beberapa diantaranya masih banyak gambar dan suara dari narasumber yang kualitasnya rendah. Kalau untuk produk jurnalistik tulis, mungkin tidak jadi masalah. Tapi kalau untuk TV, bisa menjadi masalah. Tapi memang kelebihannya dari sisi teknis $T V$, saat ini cukup menguntungkan. Dengan berbagai sumber visual dan audio dari zoom dan skype itu, kita jadi semakin banyak source. Selain itu, teknologi streaming juga memangkas proses kerja reporter dan juru kamera, yang biasanya harus mengantar atau mengirim gambar di lapangan, untuk masuk dalam dapur produksi. Kini kita bisa langsug 
olah dari tangkapan gambar streaming digital." (Novan Dwi Putranto, CNBC Indonesia).

\section{PENUTUP}

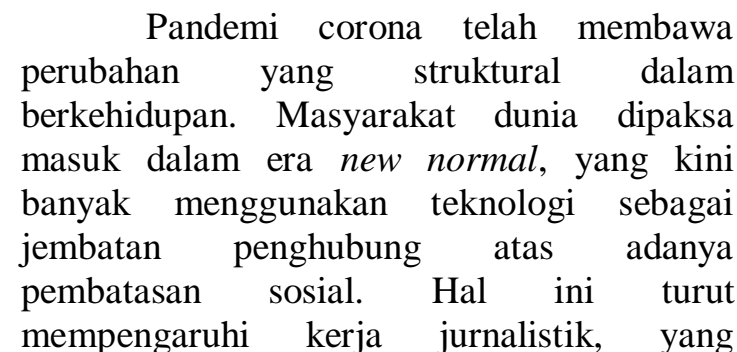
umumnya menuntut adanya mobilitas tinggi dan bertemu dengan banyak orang.

Meski demikian, seperti halnya dalam teori ekologi media, teknologi membawa perubahan dalam cara masyarakat menggunakan media. Bagi industri ini artinya adalah penyesuaian besar-besaran. Pada akhirnya membawa perubahan pada proses kerja jurnalistk.

Ada beberapa perubahan yang dialami dalam proses kerja jurnalistik TV. Diantaranya reporter kini dituntut untuk semakin memaksimalkan teknologi digital untuk mendapatkan informasi berupa gambar dan audio. Baik industri maupun narasumber, kini dipaksa untuk sama-sama siap dapat memanfaatkan teknologi tersebut. Memang, pandemi corona ini telah memaksa masyarakat masuk dalam era $4 \mathrm{G}$ dan bahkan 5G. Dimana penggunaan teknologi digital makin marak.

Selain itu, pembatasan sosial membuat reporter TV harus bisa beradaptasi lebih tinggi lagi. Diantaranya dituntut untuk bisa mengisi konten digital, dengan menulis berita-berita platform digital CNBCIndonesia.com. Ini sekaligus menjadi langkah bagi korporasi untuk meningkatkan produktivitas kerja. Namun sayangnya, perubahan pola liputan ini mendisrupsi pekerjaan camera person. Dimana pekerjaan mereka saat ini tergantikan dengan adanya teknologi streaming. Hal ini patut menjadi sinyal ancaman, akan adanya disrupsi pekerjaan di era pembatasan sosial.

Untuk itu, industri media harus siap dengan segala perubahan yang terjadi.
Termasuk bagian unit kerja yang ada di dalamnya. Pembatasan sosial membuat hentakan bagi unit tertentu dan ini menjadi tantangan bagi perusahaan untuk meminimalkan risiko yang dapat terjadi. CNBC Indonesia cukup siap dengan hentakan tersebut, dan berusaha untuk terus meningkatkan efektivitas kerja dan produksi para reporter maupun camera person.

\section{REFERENSI}

Arnani, Mela. (2020). Timeline Wabah Virus Corona.(https://www.kompas.com/tre n/read/2020/03/2/113008565/timeline -wabah-virus-corona-terdeteksi-padadesember-2019-hingga-jadi diakses pada 13 Juni 2020.

Bajari, Atwar. (2015). Metode Penelitian Komunikasi Prosedur, Tren, dan Etika. Bandung: Simbiosa Rekatama Media

Baran, Stanley J. dan Dennis K. Davis. (2010). Teori Komunikasi Massa: Dasar Pergolakan, dan Masa Depan. Jakarta: Salemba Humanika.

Creswell, John W. (2010). Research Design, Pendekatan Kualitatif, Kuantitatif, dan Mixed. Yogyakarta: Pustaka Pelajar.

Gemiharto, Ilham. (2015). Teknologi 4G-LTE dan Tantangan Konvergensi Media di Indonesia. Jurnal Kajian Komunikasi, Vol. 3, No. 2, Hal 212-220.

Halik, Abdul. (2013). Komunikasi Massa. Makassar: Alauddin University Press.

Haqqu, Rizca. (2020). Era Baru Televisi Dalam Pandangan KonvergensI Media. Jurnal Rekam, Vol. 16. No. 1.

Hidayat, Rizki. (2015). Analis Manajemen Penyiaran di Era Teknologi Informasi (Konvergensi Media). Jurnal Konvergensi, Vol. 01, No 01, Hal 119.

Jenkins, Henry. (2006) Convergence Culture: Where Old and New Media Collide. New York: New York University Press.

Kominfo. (2013). Sekilas Palapa Ring. (https://kominfo.go.id/content/detail/3 298/sekias-palapa-ring/0/palapa ring) 
diakses pada 15 Juni 2020

Lister, Martin dkk. (2009). New Media: A

Critical Introduction. News York:

Routledge.

Mulyana, Deddy dan Solatun. (2013). Metode

Penelitian Komunikasi: Contoh-

Contoh Penelitian Kualitatif Dengan

Pendekatan Praktis. Bandung:

Remaja Rosdakarya

Resmadi, Idhar dan Sonny Yuliar. (2014).

Kajian Difusi Inovasi Konvergensi Media di Harian Pikiran Rakyat. Jurnal Sosioteknologi, Vol. 13, No 2, Hal 110-118.

Stamenkovic, Ivana, dkk. (2018). The

Phenomenon of Media Multitasking in

The Digital Media Era. Series:

Teaching, Learning and Teacher

Education, Vol. 2, Hal. 71-83.

Sugihartati, Rahma. (2014). Perkembangan

Masyarakat Informasi dan Teori

Sosial Kontemporer. Jakarta: Kencana

Prenadamedia Group.

\section{BIODATA PENULIS}

Dede Suprayitno menyelesaikan pendidikan sarjana dari Jurusan Ilmu Komunikasi, Universitas Sebelas Maret Surakarta pada 2014. Saat ini tengah menyelesaikan pendidikan magister di program studi ilmu komunikasi Universitas Paramadina. Minat studi yang menjadi fokus seputar dunia jurnalistik cetak, digital dan televisi serta kajian branding. Saat ini aktif sebagai jurnalis 